\title{
Sustainability Indices in the Financial Markets, Performance and Intraday Volatility Analysis: The Case of Turkey
}

\section{Cüneyd Ebrar LEVENT iD a}

a İstanbul Aydın University, Anadolu BİL Vocational School, İstanbul, Turkey. cuneydebrarlevent@gmail.com

\begin{tabular}{|c|c|}
\hline ARTICLE INFO & ABSTRACT \\
\hline $\begin{array}{l}\text { Keywords: } \\
\text { Sustainability } \\
\text { Financial markets } \\
\text { Intraday volatility } \\
\text { CAPM }\end{array}$ & $\begin{array}{l}\text { Purpose - In the financial markets, especially the institutional investors' interest in funds and } \\
\text { portfolios composed of sustainable companies accelerated the formation of sustainability indices. In } \\
\text { this context, this study aims to examine the sustainability indices in financial markets and compare } \\
\text { the performance of Borsa İstanbul Sustainability Index (XUSRD) with benchmark indices. In this } \\
\text { study, unlike other studies in the literature, not only return performance and risk, but also intraday } \\
\text { volatility were analyzed. }\end{array}$ \\
\hline $\begin{array}{l}\text { Received } 10 \text { October } 2019 \\
\text { Revised } 14 \text { December } 2019 \\
\text { Accepted } 19 \text { December } 2019\end{array}$ & $\begin{array}{l}\text { Design/methodology/approach - The research period is between November 4, } 2014 \text { and October } \\
\text { 31,2018. The performance of the XUSRD was compared with market indices (XU100, XUTUM and } \\
\text { XTUMY) and the Corporate Governance Index (XKURY). Average daily return of indices were used } \\
\text { for return performance. Risk factor was analyzed on models established according to CAPM. } \\
\text { Intraday volatility was calculated following to the method proposed by Parkinson (1980) and } \\
\text { adapted by Corrado and Truong (2007). }\end{array}$ \\
\hline $\begin{array}{l}\text { Article Classification: } \\
\text { Research Article }\end{array}$ & $\begin{array}{l}\text { Findings - Research findings show that average daily return of XUSRD index is not different from } \\
\text { market indices and XKURY index. However, when intraday volatility is examined, it was found that } \\
\text { XUSRD was more volatile than the market indices XUTUM and XTUMY. In the three regression } \\
\text { models established according to CAPM, Jensen } \alpha \text { values were not significant, however, } \beta \text { values of } \\
\text { XUSRD were found to be higher than } 1 \text { and statistically significant. }\end{array}$ \\
\hline & $\begin{array}{l}\text { Discussion - Borsa İstanbul Sustainability Index does not provide an advantage to investors in } \\
\text { terms of return, risk and volatility. The results can be interpreted that the concept of socially } \\
\text { responsible investment is not adequately settled in Turkey. }\end{array}$ \\
\hline
\end{tabular}

\section{INTRODUCTION}

The concept of sustainability began to be widely used and debated, especially after the publication of the report, also known as the Brundtland Report, by the United Nations World Commission on Environment and Development in 1987. In the Report, which aimed to propose a "A global agenda for change" in development practices, sustainable development was defined as "development that meets the needs of the present without compromising the ability of future generations to meet their own needs" (WCED, 1987). Highlighting the differences between countries in economic and social development and the urgent needs of underdeveloped countries, this report also laid the framework for corporate sustainability, which is the business-level equivalent of sustainability. From this point of view, in both practices and academic studies, corporate sustainability has been handled with environmental, social and governance (ESG) dimensions as well as the economic dimension (Vasal, 2009; Siew, 2015; Docekalová \& Kocmanová, 2016; Ang \& Weber, 2018).

The concept of sustainability coincides with social responsibility and stakeholder approach, which states that businesses should be responsible not only to their shareholders but also to all stakeholders such as employees, customers, suppliers and society. Sustainability involves the inclusion of social and environmental issues as well as economic factors in managerial decision-making processes while consuming tangible and intangible assets and resources.

Economic sustainability can be expressed in various ratios based on the information obtained from financial reports and quantified by financial criteria such as profitability, cash ratio and turnover rates. Nevertheless

\section{Suggested Citation}

Levent, C. E. (2019) Sustainability Indices in the Financial Markets, Performance and Intraday Volatility Analysis: The Case of Turkey, Journal of Business Research-Turk, 11 (4), 3190-3203. 
measuring the social and environmental dimensions of sustainability and expressed them meaningful, quantitative and comparable is not as easy as financial criteria. Since these social and environmental issues were not identified, for many years, companies that donated to only a few non-governmental organizations or supported tree planting campaigns were assessed as fulfilling their social responsibility. This led to uncertainty in individual and institutional investors which intended to invest in socially responsible companies in financial markets.

The elimination of this uncertainty was made possible by the separation of the economic, social and environmental aspects of sustainability into categories and sub-components, their identification and the determination of quantitative criteria. Measuring corporate sustainability with quantitative criteria contributed to the increase of institutional investors' interest in the funds and portfolios of sustainable companies. This accelerated the formation of sustainability indices in the capital markets.

The aim of this study is to analyze the performance of the Borsa Istanbul Sustainability Index and to determine whether the return, volatility and risk of the index are statistically significantly different from the benchmark indices. Literature covers studies about the returns and risks of the indices mostly in developed countries. It is seen that the studies on developing countries are limited and there are few comprehensive studies on this issue. In addition, the volatilities of the indices have been examined only with their closing values and the intraday volatilitiy have been neglected. In Turkey, these issues have not been addressed sufficiently. This study aims to fill the gap in the literature by adding the intraday volatility dimension to the index performance.

In the second section following the introduction part of the study, indices such as Dow Jones Sustainability Index (DJSI) and FTSE4Good Index created in the world are examined and the contributions of sustainability indices are discussed. In the third section, Borsa Istanbul Sustainability Index in Turkey (XUSRD) are discussed, the structure and components of XUSRD are analyzed. In the fourth chapter, literature review and hypothesis development are given. The fifth section provides information about the scope, data and methodology of the research on the performance of the Borsa Istanbul Sustainability Index. Section six presents empirical results. In the last section, conclusions, discussions and recommendations are presented.

\section{SUSTAINABILITY INDICES IN THE STOCK MARKETS}

The fact that companies should not be evaluated solely on the basis of financial parameters and ratios has become widely accepted in the world especially since the last quarter of the 20th century. In this context, sustainability practices of companies have started to be seen as a criterion to be taken into consideration in structuring investment portfolios and the changing paradigm in investment has contributed to the establishment of indices in financial markets (Lopez, Garcia, \& Rodriguez, 2007).

It is possible to specify the starting point of sustainability indices as socially responsible investments (SRI) and socially responsible funds. The portfolios consisting of companies that have embraced social responsibility have attracted the attention of institutional investors particularly in developed countries. The fact that there is an orientation towards the stakeholder approach rather than the shareholder approach has an important effect on this. The application of economic, social and environmental activities with sustainability criteria can be expressed as a result of globalization that the markets have experienced and the growing demand of stakeholders for transparency (Lassala, Apetrei, \& Sapena, 2017).

Although social responsibility and sustainability may differ slightly in conceptual terms, social responsibility and sustainability indices are considered together in both academic studies and practices. In accordance with their responsibility mission, regulatory agencies established sustainability indices to encourage companies whose shares were traded in capital markets to be sustainable.

The fact that companies are aware of their responsibilities to environment, society, employees, shareholders, customers, suppliers, creditors and in short all stakeholders actually helps companies' activities to continue in the future. The inclusion of a publicly traded company in an index of sustainable companies contributes both to their management in this direction and to the institutionalization of sustainability activities. Moreover, institutional investors and funds, which have a significant weight in capital markets, may prefer sustainable companies. This may increase the financing opportunities of the company. In addition, being in the sustainability index can help to increase the corporate reputation of the company among the stakeholders and to ensure that qualified employees prefer the company. 
The first index consisting of social responsible companies for financial markets was the Domini 400 Social Index, created in 1990 (Cunha \& Samanez, 2013). Nine years later, the Dow Jones Sustainability Index (DJSI) which was launched firstly under the name "sustainability", was established. Due to the interest of investors in the DJSI, sub-indices such as DJSI-North America, DJSI-Asia Pacific, DJSI-Europe, DJSI-Emerging Markets, DJSI-Korea, DJSI-Australia were created. (RobecoSAM, 2018).

On the other side of the Atlantic, the FTSE4Good Index on the London Stock Exchange started to be calculated in 2001. In the following years, this index also developed and became an index that included many sub-indices like DJSI. Today, FTSE4Good indices not only provide financial instruments focused on sustainable investments, but also contribute to the identification of environmentally and socially sustainable companies and the development of a global ESG standard (FTSE, 2019).

Following the DJSI and FTSE4Good indices, sustainability indices were launched in stock exchanges in Germany, Spain, Austria, Denmark, Sweden, Norway and other developed countries. Among the developing countries, the first sustainability index was established in 2004 on the Johannesburg Stock Exchange in South Africa (Orsato et al., 2015).

In 2009, sustainability indices were established in Korea, Indonesia and China (Shanghai Stock Exchange) and in 2010 on the Egypt Stock Exchange. Sustainability Index launched in Turkey in 2014, it can be specified as late as compared to the developing countries in this regard. In the next section, Borsa İstanbul Sustainability Index is examined in more detail.

\section{BORSA ISTANBUL SUSTAINABILITY INDEX}

Borsa İstanbul (BIST) established Sustainability Index (XUSRD) to promote the environmental, social and corporate governance practices of publicly traded companies. Since 4th of November 2014, XUSRD has been calculated as price and return index respectively.

There were several suggestions regarding the establishment of the sustainability index in Turkey. However, serious efforts related to the establishment of the index started in 2013. Borsa İstanbul signed an agreement with Ethical Investment Research Services Limited (EIRIS) which provided services to various stock exchanges in order to ensure the sustainability index to be institutionalized. According to this agreement, EIRIS evaluates BIST companies in the field of environmental, social and corporate governance. In sustainability assessment, additional information is not requested from companies, only publicly available company information is used (BIST, 2014, 2019a).

The prerequisite for inclusion in XUSRD is that the company is subject to sustainability assessment. In the current practice, companies listed in BIST 50 do not need to apply separately for assessment. Companies other than BIST 50 are included in the evaluation process upon request by companies. To inclusion in XUSRD, companies are required to meet certain criteria in the "BIST Sustainability Index Research Methodology". These criteria consist of the following main topics (BİST, 2015):

\section{"1-Environment}

2-Biodiversity

3-Climate Change

4-Board Practice

5-Countering Bribery

6-Human Rights

7-Supply Chain

8-Health and Safety

9-Banking Criteria (for Banks)"

XUSRD was launched on November 4, 2014 as mentioned above. The companies in the XUSRD were selected from BIST 30 companies when the index started to be calculated. Therefore, the closing value of the BIST 30 index on 3rd November 2014 (98.020) was taken as the initial value of the XUSRD index. 
XUSRD is calculated as both price and return index. The price index is calculated every 10 seconds during the session period and disseminated in real time through licenced data distributors. The return index is disseminated once at the end of the day. The following formula (1) is used to calculate the index (BİST, 2017):

$$
\mathrm{E}_{\mathrm{t}}=\frac{\sum_{\mathrm{i}=1}^{\mathrm{n}}\left(\mathrm{F}_{\mathrm{it}} / \mathrm{D}_{\mathrm{t}}\right) * \mathrm{~N}_{\mathrm{it}} * \mathrm{H}_{\mathrm{it}} * \mathrm{~K}_{\mathrm{it}}}{\mathrm{B}_{\mathrm{t}}}
$$

\author{
"Et: Sustainability Index value at time $t$ \\ $n$ : Number of companies included in the index \\ $F_{i t}$ : Price of the " $i$ "th stock at time $t$ \\ $N_{i t}$ : Total number of shares of stock " $i$ " at time $t$ \\ $H_{i t}$ : Free float ratio used in index calculation of the stock " $i$ "th at time $t$ \\ $K_{i t}$ : Coefficient (Weighting Factor) of the stock " $i$ " at time $t$ \\ $D_{t}$ : Foreign exchange rate on day " $t$ " \\ Bt: Divisor of the index at time t" (BİST, 2017)
}

\title{
4. LITERATURE REVIEW and HYPOTHESIS DEVELOPMENT
}

There are various studies on the performance of sustainability or responsible investment indices in stock markets. These studies are examined in detail and the findings are presented below.

Research on responsible investments has been concentrated, especially after the formation of sustainability indices. DiBartolomeo and Kurtz (1999) researched on the risk of Domini Social Index, Sauer (1997) studied on Domini Social Index and Domini Equity Mutual Fund. Another researcher working on this subject, Statman (2000) stated that the Domini Social Index got better return than the S\&P 500 Index and that socially responsible mutual funds outperform traditional mutual funds. However, Statman found that the differences between their risk-adjusted returns were not statistically significant.

The establishment of the Dow Jones Sustainability Index (DJSI) triggered studies on the sustainability index. Garz, Volk and Gilles, (2002), in their DJSI studies, discussed whether sustainability was a value-adding factor and showed the risk / return profile of the index based on average monthly returns. Schröder (2007) investigated the performance of socially responsible investment indices and conventional market indices. The author examined 29 socially responsible investment indices, including the Dow Jones Sustainability Index (DJSI) and the FTSE4Good Index. He found that the average return of SRI indices was higher in 17 out of 29 indices than in conventional indices. In the following years, Consolandi et al. (2009) demonstrated that the Dow Jones Sustainability Stoxx Index (DJSSI) offered more average daily returns between 1999 and 2006 compared to the DJSI index.

The risk of the sustainability index has also been an important field of study. Benson, Gupta and Mateti (2010) who examined the Dow Jones Sustainability Index, investigated the performance of sustainable companies in the context of risk. In the study using monthly returns, the findings showed that sustainable companies were less risky than other companies.

As mentioned before, sustainability, socially responsible (SRI) and ethical investments can be examined together in the literature. Belghitar, Clark and Deshmukh, (2014) sought an answer to the question, "Does it pay to be ethical?" and conducted a comparative study of five different social responsibility and sustainability indices calculated in the UK in FTSE. The authors stated that they provided strong evidence that their results were a financial price worth paying for socially responsible investments.

Sustainability indices were also studied in stock exchanges other than the US and UK. There was no evidence that the index performed comparatively better after the sustainability index was established in Brazil (Cavalcante, Bruni, \& Costa, 2007; Rezende, Nunes, \& Portela, 2007; Machado, Machado, \& Corrar, 2009). Also in Brazil, Cunha and Samanez (2013) found that the Sustainability Index performed lower than the main index 


\section{E. Levent 11/4 (2019) 3190-3203}

BOVESPA and sustainability did not provide investors with an advantage in terms of liquidity level, return and risk.

Ang (2015) found that the performance of the sustainable investment portfolio represented by the Dow Jones Sustainability Index-Korea (DJSIK) is higher than most of the conventional portfolios in Korea. Sudha (2015) studied on the sustainability index (S\&P ESG India Index) on the Indian Stock Exchange. She compared the sustainability index performance with the two major market indices using daily index data, and also analyzed volatility. The author found that the daily compound return of the ESG index was not statistically different from Nifty and CNX 500 indices which were selected as market indices. However, she emphasized that the annual returns of the ESG index were better than the returns of the other two indices.

In this regard, there is not enough research on the Turkish financial market. Gök and Özdemir (2017) researched on conditional volatility estimation of Sustainability Index and BIST 100 Index within the framework of EGARCH model. The authors found that the volatility persistence of both indices was high and that negative shocks had a higher effect on volatility than positive shocks. Çıtak and Ersoy (2016) investigated the investors' reaction to the inclusion of companies in the BIST Sustainability Index. In the study, they found that the average of abnormal return did not differ from zero in all days in the event window of 10 days before and after announcement day.

In this research the following hypotheses will be tested by taking into account the studies in the literature:

Hypothesis 1: The average daily return of the Borsa İstanbul Sustainability Index (XUSRD) is different from the benchmark indices (XU100, XUTUM and XTUMY).

Hypothesis 2: The intraday volatility of the Borsa İstanbul Sustainability Index (XUSRD) is different from the benchmark indices (XU100, XUTUM and XTUMY).

Hypothesis 3: The average daily return of the Borsa İstanbul Sustainability Index (XUSRD) is different from the Borsa İstanbul Corporate Governance Index (XKURY).

Hypothesis 4: The intraday volatility of the Borsa İstanbul Sustainability Index (XUSRD) is different from the Borsa İstanbul Corporate Governance Index (XKURY).

Hypothesis 5: The $\beta$ value (according to CAPM) of the Borsa İstanbul Sustainability Index (XUSRD) is different from the benchmark indices (XU100, XUTUM and XTUMY).

\section{DATA and METHODOLOGY}

\subsection{Scope of the Research}

The research covers Borsa Istanbul (BIST) and aims to determine whether the return, volatility and risk of the BIST Sustainability Index differ statistically from the benchmark indices. The BIST 100 index (XU100) is usually used as proxy for the market return in both index-based and stock-based research for Turkey. In this study, in addition to the XU100, BIST All Index (XUTUM) and BIST All-100 Index (XTUMY) indices are examined as benchmarks. So, the research covers the index consisting of more companies.

\subsection{Data Set and Methodology}

BIST Sustainability Index started to be calculated with XUSRD code as of November 4, 2014. Borsa Istanbul (BIST), which is regulatory body in Turkey, currently calculates 330 indices including XUSRD (BIST, 2019b) and disseminates in real time through licenced data distributors. The data of indices are also published on the BIST Website at the end of the session. Therefore, the raw data (open, close, high and low values during the session) used in this study was obtained from the BIST Website.

In this study, the performance of XUSRD is compared with three market indices (benchmark indices). In addition, the BIST Corporate Governance Index, which is similar to the Sustainability Index, but has differences in inclusion rules, is also examined in the study. The indices examined in the study are given in Table 1: 


\section{E. Levent 11/4 (2019) 3190-3203}

Table 1: Indices Used In The Research

\begin{tabular}{ll}
\hline Stock Indices & Definition \\
\hline XU100 (BIST 100 Index) & $\begin{array}{l}\text { It is the main index of Borsa Istanbul. It consists of 100 stocks that meet } \\
\text { various criteria. }\end{array}$ \\
XUTUM (BIST All Index): & $\begin{array}{l}\text { The index consists of all stocks of companies traded on Borsa İstanbul } \\
\text { markets, except Investment Trusts. } \\
\text { XTUMY (BIST All-100 Index): }\end{array}$ \\
$\begin{array}{l}\text { The index consists of the stocks of companies which are included in BIST } \\
\text { All Index but not in BIST 100 Index. } \\
\text { XKURY (BIST Corporate } \\
\text { The index consists of the stocks of companies traded on Borsa İstanbul } \\
\text { markets which have the minimum required corporate governance rating } \\
\text { grade. }\end{array}$ \\
\hline
\end{tabular}

Source: The descriptions were taken from Borsa İstanbul (BIST, 2019b).

The research period is between November 4, 2014 and October 31, 2018. Since the sustainability index period starts in November and ends at the end of October, the scope of the research is determined accordingly. The data set of the study consists of 1006 days of data between these dates. The daily return of an index is calculated by the following equation (2):

$$
r_{t}=\frac{C_{t}-C_{t-1}}{C_{t-1}}
$$

rt: Daily return of index

$C_{t}:$ Closing value on the " $t$ " th day of the index

$\mathrm{C}_{\mathrm{t}-1:}$ : Closing value on the " $\mathrm{t}-1$ " th day of the index

In the study, the intraday volatilities of the indices are also analyzed. Intraday volatility can be calculated by different methods. Intraday high-low range volatility method is preferred for this research. This method was first proposed by Parkinson (1980) in the literature. Corrado and Truong (2007) adapted this method to measure intraday volatility in the S\&P 500, S\&P 100, NASDAQ 100 and Dow Jones Industrials indices. This method is based on the high and low values that indices reach during the trading session, rather than the closing value. Intraday high - low range volatility is calculated by the following equation (3):

$$
R N G_{t}^{2}=\frac{\ln ^{2}\left(h i_{t} / l o_{t}\right)}{4 \ln 2}
$$

Where;

$\mathrm{RNGt}^{2}$ : intraday high-low range volatility

hi : the current period's high during the trading interval

lo : the current period's low during the trading interval

Calculating the performance of the indices only on the basis of their raw returns leads to neglect of their risks. Therefore, in this study, the performance of XUSRD is also examined within the framework of the Capital Asset Pricing Model (CAPM). CAPM is one of the most important models used to analyze the relationship between risk and return of financial assets. In the study, following the method used by Sauer (1997), Schröder (2007), Benson, Gupta and Mateti (2010), Ortas, Moneva and Salvador (2010) the Equation (4) is applied:

$$
r_{X U S R D}-r_{f}=\alpha_{X U S R D}+\beta\left(r_{m}-r_{f}\right)+\varepsilon
$$

Where;

$r$ XUSRD: daily return of the XUSRD index

$\mathrm{rf}_{\mathrm{f}}$ : risk-free rate of return 
$\mathrm{r}_{\mathrm{m}}$ : daily return of the market (benchmark index)

$\alpha$ XUSRD : Jensen' alpha (daily abnormal return from the OLS model)

$\beta$ : beta of the XUSRD index

$\varepsilon$ : error term

As risk-free interest rate $\left(\mathrm{r}_{\mathrm{f}}\right)$, overnight interest rates announced by The Central Bank of the Republic of Turkey (TCMB, 2019) are used. For use in Equation 4, annual interest rates are converted into daily rates. The market returns are represented by the returns of the XU100, XUTUM and XTUMY indices as previously mentioned, and these rates are calculated on a daily basis. According to CAPM, if $\beta$ is greater than 1, the risk of XUSRD is higher than the market index, and lower than 1 indicates that the risk is less (Schröder, 2007:337). The Jensen alpha value represents the average risk premium per systemic risk unit and therefore, it is considered an appropriate risk-adjusted measure of portfolio performance for investors that are well diversified and primarily concerned with their exposure to systematic risk (Sauer, 2007:143). In the study, these coefficients are estimated by OLS (Ordinary Least Squares) regression model established within the framework of CAPM model. Stata program is used for this analysis.

\section{FINDINGS}

In this section, the results of the research on return, volatility and risk of BIST Sustainability Index and benchmark indices are presented. At first, the returns of the indices are examined.

Table 2: Total return performance of indices

\begin{tabular}{lrrr}
\hline & $\mathbf{4 . 1 1 . 2 0 1 4}$ Close & 31.10.2018 Close & Return \% \\
\hline XUSRD & 96.593 & 113.825 & $17,84 \%$ \\
XU100 & 78.956 & 90.201 & $14,24 \%$ \\
XUTUM & 78.826 & 91.241 & $15,75 \%$ \\
XTUMY & 89.635 & 120.977 & $34,97 \%$ \\
XKURY & 69.292 & 79.093 & $14,14 \%$ \\
\hline
\end{tabular}

Table 2 shows the 4-year return performances of XUSRD and other indices. From November 2014 to October 2018, total return of XUSRD is $17.84 \%$ and yields more return than XU100 and XUTUM. But XTUMY, which is another benchmark index, has approximately twice as much return performance (34.97\%) as all indices. The lowest return among the indices is found in the Corporate Governance Index (XKURY).

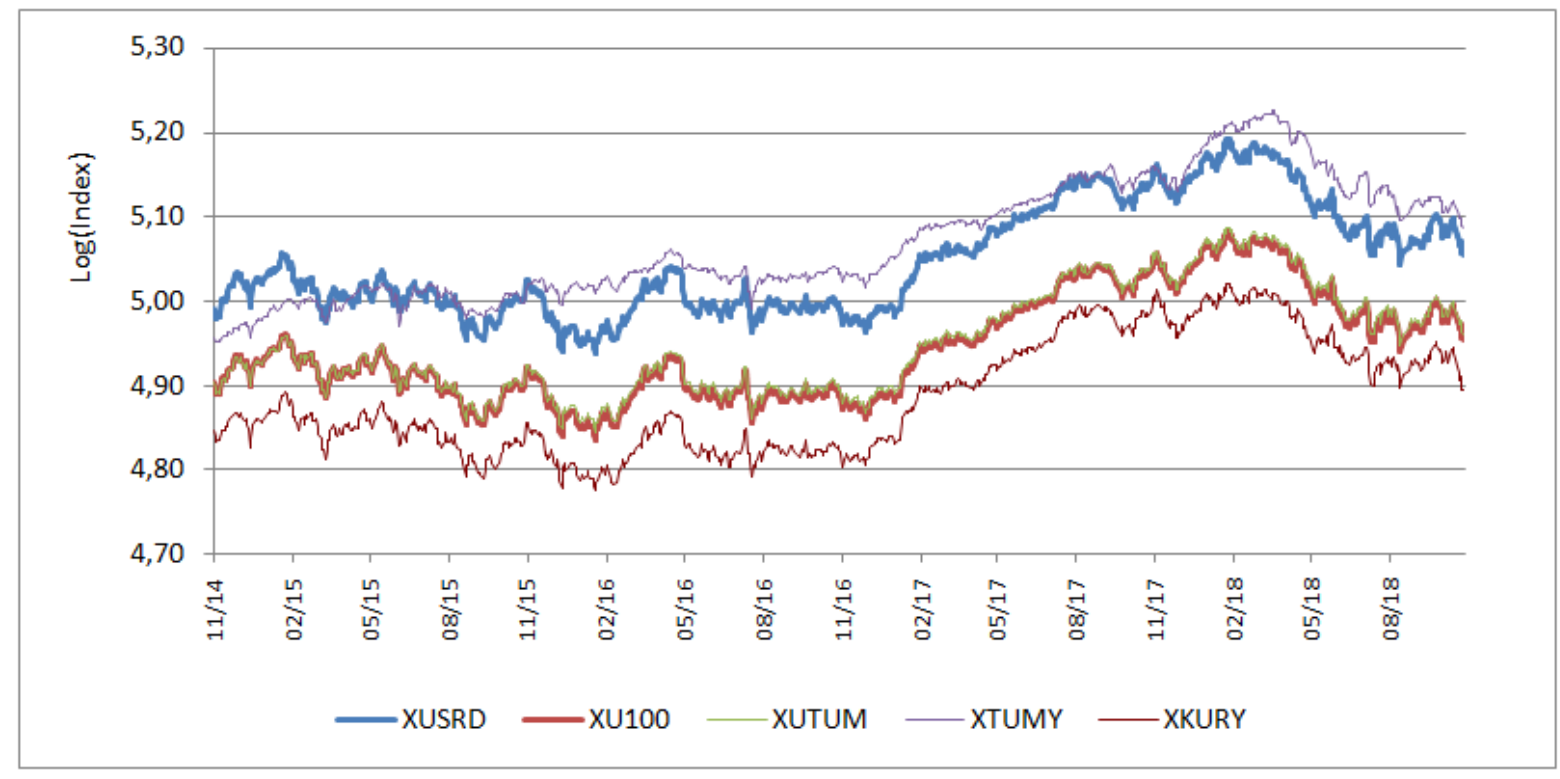

Figure 1: Daily close chart of the indices 


\section{E. Levent 11/4 (2019) 3190-3203}

Figure 1 shows the four-year trend of the indices (in logarithmic scale) arranged to daily closing data. Although in November 2014, the BIST Sustainability Index was higher than the XTUMY index, at the end of the four-year period, it closed with a value below XTUMY. However, it can be said that all indices, including XUSRD, move parallel with the upward and downward trends in the stock market. Figure 2 shows the daily return rates of the indices. The impact of the up and down shocks on the indices can be observed in Figure 2 more clearly.
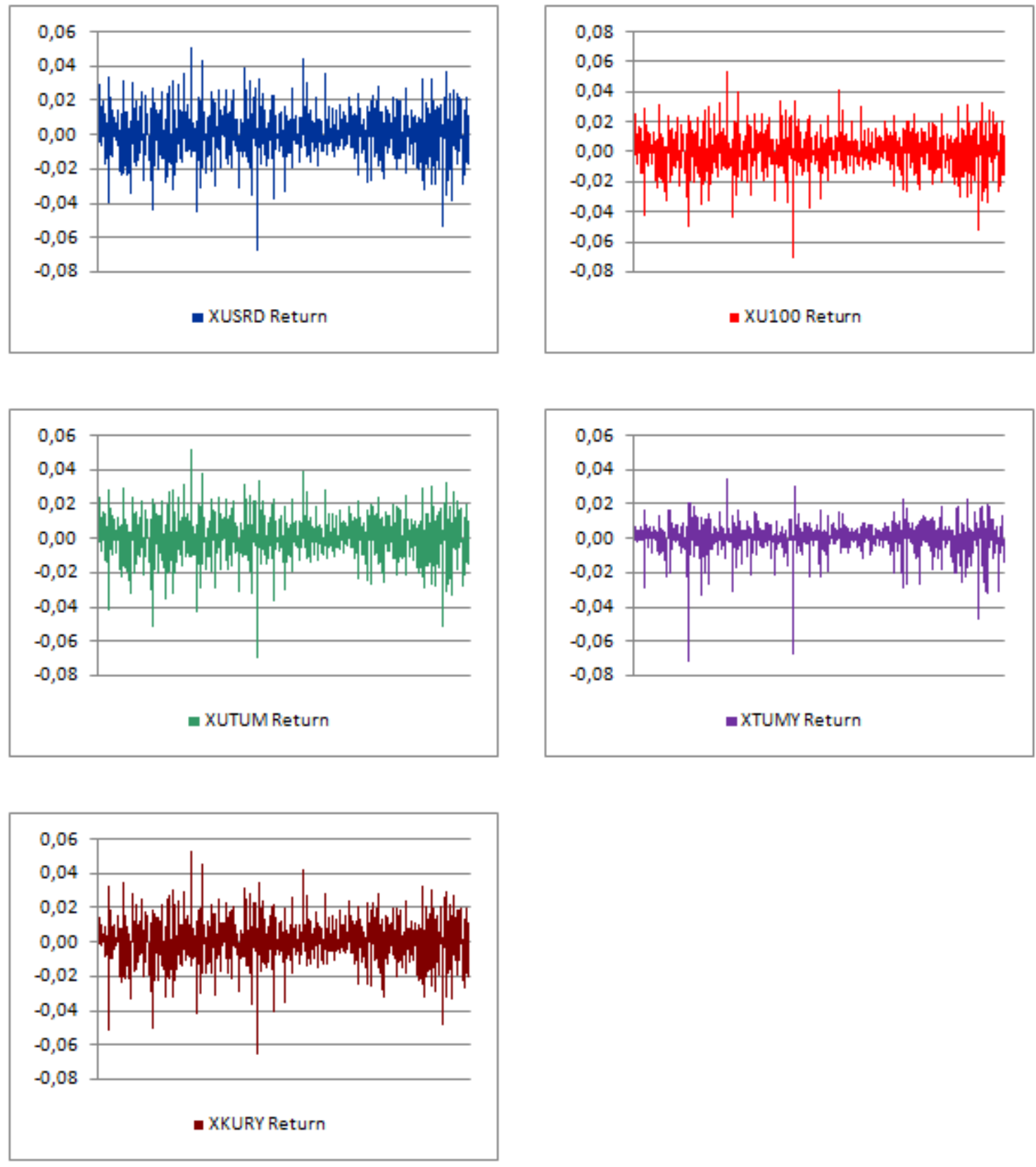

Figure 2: Daily Return Chart of XUSRD and Benchmark Indices 
C. E. Levent 11/4 (2019) 3190-3203

Table 3: Descriptive Statistics

\begin{tabular}{lrrrrr}
\hline \multicolumn{1}{c}{ Variables } & $\mathbf{N}$ & Mean & Minimum & Maximum & Std. Deviation \\
\hline rxUSRD & 1006 & 0,00024 & $-0,06817$ & 0,05191 & 0,01355 \\
rxU100 & 1006 & 0,00020 & $-0,07084$ & 0,05396 & 0,01289 \\
rxUTUM & 1006 & 0,00021 & $-0,07066$ & 0,05259 & 0,01245 \\
rxTUMY & 1006 & 0,00033 & $-0,07201$ & 0,03564 & 0,00895 \\
rxKURY & 1006 & 0,00020 & $-0,06640$ & 0,05319 & 0,01298 \\
RNG $^{2}$ xUSRD & 1006 & 0,00013 & $2,89 \mathrm{E}-06$ & 0,00343 & 0,00019 \\
RNG $^{2}$ хU100 & 1006 & 0,00012 & $3,17 \mathrm{E}-06$ & 0,00353 & 0,00018 \\
RNG $^{2}$ хUTUM & 1006 & 0,00010 & $2,09 \mathrm{E}-06$ & 0,00339 & 0,00017 \\
RNG $^{2}$ хтUмY & 1006 & $5,43 \mathrm{E}-05$ & $2,37 \mathrm{E}-06$ & 0,00267 & 0,00013 \\
RNG $^{2}$ хкURY & 1006 & 0,00012 & $2,67 \mathrm{E}-06$ & 0,00407 & 0,00020 \\
\hline
\end{tabular}

Table 3 shows descriptive statistics. Daily average returns (shown by r) are calculated according to the Equation (2). The average daily return of the XUSRD index $(0.024 \%)$ is higher than the indices other than the XTUMY, as stated in Table 2. When the standard deviations are examined, it is seen that the standard deviation of XUSRD is higher than all other indices.

The method recommended by Parkinson (1980) is used to determine the intraday volatility (RNG ${ }^{2}$ ) of the indices. For implementation of the method Corrado and Truong (2007) is followed (Equation 3). This method uses intraday high and low values, not closing values, unlike other methods. The RNG ${ }^{2}$ values in Table 3 show that the average intraday volatility of the BIST Sustainability Index is higher than the other four indices.

In the next stage, it is investigated whether the differences in the indices are statistically significant. For this purpose, the average return and intraday volatilities of the XUSRD index are compared with the XU100, XUTUM and XTUMY indices, which are determined as benchmark indices, with the $t$ test (Table 4). It is considered that the number of data is sufficiently large $(\mathrm{N}=1006)$ and $t$ test is preferred following similar studies in the literature (Statman, 2000; Consolandi et al., 2009; Belghitar, Clark, \& Deshmukh, 2014).

Table 4: Average Daily Return and Intraday Volatility Comparison

\begin{tabular}{lccrr}
\hline & Model 1 & Model 2 & Model 3 & Model 4 \\
\hline Benchmark Index & XU100 & XUTUM & XTUMY & XKURY \\
\hline Return Performance & & & & \\
\hline $\mathrm{t}$ statistic & 0,0687 & 0,0563 & $-0,1720$ & 0,0664 \\
Prob. & 0,9452 & 0,9551 & 0,8635 & 0,9471 \\
\hline Intraday Volatility & & & 10,1673 & 1,1236 \\
\hline t statistic & 1,5766 & 2,9568 & $0,0000^{* * *}$ & 0,2613 \\
Prob. & 0,1151 & $0,0031^{* * *}$ &
\end{tabular}

*** Statistically significant at $1 \%$ level

In Model 1, the daily return and intraday volatility of XUSRD is compared with XU100 which is the main index of Borsa İstanbul (Table 4). When the return performances are examined, the probability value of the $t$ statistic is 0.9452 . This result shows that the difference between the two indices is not statistically significant. In the case of intraday volatility, the probability value of 0.1151 indicates that the difference is not significant.

In Model 2, XUTUM is selected as a benchmark index. No significant results are found in this model for return performance $(P>0,01)$. In return volatility, the probability of $t$ statistic is found 0.0031 , which is greater than 0.01 . This means that there is a significant difference between the two indices in terms of volatility.

The index XTUMY consists of the stocks of companies which are included in BIST All Index but not in BIST 100 Index. The model established with this index is expressed with Model 3. In both Table 2 and Table 3, the return of the XTUMY index is shown to be higher than the other indices. As shown in Table 4, the difference is not statistically significant based on daily returns and $t$ statistical probability value $(P=0,8635>0,01)$. 
However, when intraday volatility is taken into account, the difference between XTUMY and XUSRD is significant $(\mathrm{P}=0,0000<0,01)$.

Although XKURY index is not an index representing market return, differences between Corporate Governance Index and Sustainability Index are examined in Model 4. This is because the two indices have structural similarity. The results show that the differences between the two indices, both return performance and intraday volatility, are not statistically significant.

In the context of developed hypotheses, when Table 4 examined as a whole, the results show that the null hypotheses (Hypothesis 1 and Hypothesis 3) that the average daily return of the XUSRD index does not differ from the other indices (XU100, XUTUM, XTUMY and XKURY) are accepted, so alternative hypotheses are rejected. The null hypothesis (Hypothesis 2), which suggests no differences in intraday volatility, is accepted for XU100 and rejected for XUTUM and XTUMY. The null hypothesis (Hypothesis 4), which states that intraday volatility of XKURY is not different from XUSRD, is accepted, alternative hypothesis is rejected.

In summary, there is no statistical difference between XUSRD and other indices in terms of average return performance. The findings do not support expectations, and many studies especially in the USA and UK. However, the results are consistent with Cavalcante, Bruni and Costa (2007), Rezende, Nunesa and Portela (2007), Machado, Machado and Corrar (2009) for the Brazilian Stock Exchange. In terms of intraday volatility, the difference between XUSRD and XU100 is not significant, but significant with XUTUM and XTUMY. There is no statistically significant difference between XUSRD and XKURY both in terms of return performance and intraday volatility.

The return of XUSRD is also analyzed according to the Capital Asset Pricing Model (CAPM). Three different OLS (Ordinary Least Squares) regression models are established within the framework of CAPM model and the relationship between XUSRD and indices chosen as market portfolios is investigated. According to these models, $\alpha$ and $\beta$ coefficients in the models are estimated. The analysis results are given in Table 5.

Table 5: OLS Regression Results of Models Based on CAPM

\begin{tabular}{|c|c|c|c|c|}
\hline & & Model 5 & Model 6 & Model 7 \\
\hline \multicolumn{2}{|c|}{ Benchmark Index } & XU100 & XUTUM & XTUMY \\
\hline \multirow[t]{4}{*}{$\mathrm{C}$} & $\alpha$ & 0,00004 & 0,00003 & $-0,00011$ \\
\hline & Robust Std. Err. & 0,00006 & 0,0001 & 0,0003 \\
\hline & $\mathrm{t}$ statistic & 0,68 & 0,5200 & $-0,4100$ \\
\hline & Prob. & 0,4960 & 0,6020 & 0,6830 \\
\hline \multirow[t]{4}{*}{$\mathbf{R m}-\mathbf{R f}$} & $\beta$ & 1,04008 & 1,0752 & 1,1971 \\
\hline & Robust Std. Err. & 0,00628 & 0,0081 & $-0,0497$ \\
\hline & t statistic & 165,58 & 132,1700 & 24,1000 \\
\hline & Prob. & $0,0000^{* * *}$ & $0,0000^{* * *}$ & $0,0000^{\text {*** }}$ \\
\hline \multicolumn{2}{|l|}{$\mathbf{R}^{2}$} & 0,9494 & 0,9760 & 0,6263 \\
\hline \multicolumn{2}{|l|}{ F statistic } & 27415,72 & 17468,73 & 580,86 \\
\hline \multicolumn{2}{|l|}{ F prob. } & $0,0000^{* * *}$ & $0,0000^{* * *}$ & $0,0000^{* * *}$ \\
\hline \multicolumn{2}{|l|}{$\mathbf{N}$} & 1006 & 1006 & 1006 \\
\hline
\end{tabular}

All three models established according to the results given in Table 5 are significant at the $1 \%$ significance level (F prob $=0.0000<0.01$ ). When the correlation between XUSRD and benchmark indices is examined, it is found that the correlation coefficients in the models established with XU100 in Model 5 and XUTUM in Model 6 are very high (94.94\% and $97.60 \%$ ). In Model 7, the correlation between the XUSRD and XTUMY is $62.63 \%$ that is lower than the other two models, but even this correlation can be considered as high. 


\section{E. Levent 11/4 (2019) 3190-3203}

The main purpose of these regression models is to estimate the $\alpha$ (Jensen alpha) and $\beta$ coefficients specified in the Equation (4) rather than the determination of correlations. The results of Jensen alpha values in Table 5 show that the relative risk-adjusted returns of XUSRD do not statistically differ significantly from benchmark indices. However, the values of alpha coefficients are close to zero, similar to the results of the study found by Ortas, Moneva and Salvador (2010). Although the XUSRD index performs better than the XU100 and XUTUM indices and performs worse than the XTUMY index, the alpha coefficients indicate that these differences are not very high.

When the beta coefficients given in Table 5 are considered, the beta values of the XUSRD index are found higher than 1 in all three models. These results are statistically significant. The results show that the alternative hypothesis (Hypothesis 5), which assumes that the beta of the Borsa İstanbul Sustainability Index (XUSRD) calculated according to the CAPM, is different from the comparison indices, is accepted. This shows that the risk of the XUSRD index is higher than the market indices. When the XTUMY index is selected as the market return, the beta value of XUSRD is 1,1971. These findings indicate that the BIST Sustainability Index offers investors a return that does not meet the risk.

\section{CONCLUSION}

Today, the traditional approach, which focuses solely on protecting the interests of shareholders, has become obsolete. Companies also have responsibilities to the stakeholders in which they affect their activities. The concept of corporate sustainability, which includes the concept of social responsibility, is based on not to jeopardize the ability of future generations to meet their needs while meeting the current needs of enterprises (WCED, 1987). In this respect, especially for publicly traded companies, it is necessary to recognize that sustainability is not only an ethical approach but also an economic factor. For example, companies that pollute the environment, employ child workers, and do not comply with health and safety rules face large fines, lose customers and are also punished by financial markets (decrease of stock price). The importance of the concept of sustainability and increased interest in sustainable investments have led to the creation of sustainability indices in the stock markets.

In this study, sustainability indices in the financial markets were examined, structural characteristics of the Borsa İstanbul Sustainability Index (XUSRD) were explained and performance was analyzed. Moreover, XUSRD's performance was compared with market indices and the Corporate Governance Index. In both index-based and stock-based research conducted for Turkey, the BIST 100 index (XU100) have been usually taken as the representative of the market return. In this study, XUTUM (BIST All Index) and XTUMY (BIST All-100 Index) indices were also examined as benchmark indices. So, the research covered the index consisting of more companies. The return performance was analyzed by calculating the average daily returns of the indices.

One of the most important contributions of this study to the literature is the analysis of intraday volatility. For this purpose, intraday volatility was calculated according to the method proposed by Parkinson (1980) and adapted by Corrado and Truong (2007). This method is based on the high and low values that indices reach during the trading session, rather than the closing value. In addition, the return of XUSRD was analyzed according to CAPM and three OLS regression models were established and $\alpha$ and $\beta$ coefficients in the models were estimated.

The results show that during the 4-year period, the XUSRD index yielded more returns than the XU100, XUTUM, and XKURY indices, and lower than the XTUMY index. In order to determine the statistical significance of the differences in the indices, the average daily return averages of the XUSRD index were compared with other indices. The research findings show that the daily average return of the XUSRD index was not statistically different from all four indexes examined. Although these results do not support the studies in developed countries, they are consistent with the emerging market studies of Cavalcante, Bruni and Costa (2007), Rezende, Nunesa and Portela (2007), Machado, Machado and Corrar (2009) on the Brazil Stock Exchange.

When the intraday volatility was examined, it was found that XUSRD is more volatile than the market indices XUTUM and XTUMY. However, no statistically significant volatility difference was found between XUSRD and XU100 and between XUSRD and XKURY. 
In the three regression models established according to CAPM, Jensen $\alpha$ values were not significant, however, $\beta$ values of XUSRD were found to be statistically significant and higher than 1 . The fact that $\beta$ is greater than 1 indicates that the risk of XUSRD is higher than the market indices.

As a consequence of the findings, it was found that XUSRD index did not provide an advantage to investors in terms of return, risk and volatility. The results can be interpreted that the concept of socially responsible investment is not sufficiently settled in Turkey. Furthermore, considering that the establishment of the sustainability index is new in Turkey, it can be concluded that not only individual investors but also institutional investors are not as interested in the sustainability index as they should be.

Based on the result on the study, it is useful to specify some suggestions. The findings should not be interpreted as meaning that the concept of sustainability is not suitable for Turkey or Turkish companies should focus only on economic sustainability. On the contrary, it should be taken into account the fact that sustainable development and sustainable growth will have long-term contributions to both country and company level. It should be considered that companies' activities such as energy efficiency, resource utilization and recycling of wastes will contribute to economic sustainability in addition to the function of fulfilling the requirements of environmental sustainability.

The research also presents some suggestions to investors. The results show that the sustainability index provides no extra benefit to investors in terms of average daily return. In addition, the beta and intraday volatility of the index were found to be higher than the benchmark indices. Therefore, investors are recommended to consider to these factors when deciding on socially responsible investments.

This study has several limitations. First, the research covers only a country (Turkey). Another limitation is the time dimension. The study covers a restricted time period of 4 years due to the establishment of the Sustainability Index in Turkey at the end of 2014. For future research, it is recommended to follow the similar methodology and analyze the sustainability-performance relationship for longer time periods.

\section{REFERENCES}

Ang, W. R. (2015). Sustainable investment in Korea does not catch a cold when the United States sneezes. Journal of Sustainable Finance \& Investment, 5(1-2) , 16-26.

Ang, W. R., \& Weber, O. (2018). The market efficiency of socially responsible investment in Korea. Journal of Global Responsibility, 9(1), 96-110.

Belghitar, Y., Clark, E., \& Deshmukh, N. (2014). Does it pay to be ethical? Evidence from the FTSE4Good. Journal of Banking \& Finance, $47,54-62$.

Benson, C. C., Gupta, N. J., \& Mateti, R. S. (2010). Does Risk Reduction Mitigate the Costs of Going Green? An Empirical Study of Sustainable Investing. Southern Journal of Business and Ethics, 2 , 7-25.

BİST. (2014). Şirketler İçin Sürdürülebilirlik Rehberi. Retrieved from https://www.borsaistanbul.com/data/kilavuzlar/surdurulebilirlik-rehberi.pdf

BIST. (2015). BIST Sustainable Index Research Methodology. Retrieved from https://www.borsaistanbul.com/en/indices/bist-stock-indices/bist-sustainability-index

BİST. (2017). BIST Sürdürülebilirlik Endeksi Temel Kurallar. Retrieved from http://www.borsaistanbul.com/docs/default-source/endeksler/bist-sustainability-index-groundrules.pdf?sfvrsn=8

BİST. (2019a). BISST Sürdürülebilirlik Endeksi. Retrieved from https://www.borsaistanbul.com/endeksler/bistpay-endeksleri/surdurulebilirlik-endeksi

BIST. (2019b). Borsa Istanbul. Retrieved from http://www.borsaistanbul.com/en

Cavalcante, L. R., Bruni, A. L., \& Costa, F. J. (2007). Sustentabilidade Empresarial e Desempenho Corporativo: Uma Análise do Mercado Brasileiro de Ações. XXXI Encontro da ANPAD. Rio de Janeiro . 


\section{E. Levent 11/4 (2019) 3190-3203}

Consolandi, C., Jaiswal-Dale, A., Poggiani, E., \& Vercelli, A. (2009). Global Standards and Ethical Stock Indexes: The Case of the Dow Jones Sustainability Stoxx Index. Journal of Business Ethics, Vol.87 , 185197.

Corrado, C., \& Truong, C. (2007). Forecasting stock index volatility: Comparing implied volatility and the intraday high-low price range. The Journal of Financial Research, 30(2) , 201-215.

Cunha, F. A., \& Samanez, C. P. (2013). Performance Analysis of Sustainable Investments in the Brazilian Stock Market: A Study About the Corporate Sustainability Index (ISE). Journal of Business Ethics, 117(1) , 1936.

Çıtak, L., \& Ersoy, E. (2016). Firmaların BIST Sürdürülebilirlik Endeksine Alınmasına Yatırımcı Tepkisi:Olay Çalışması Ve Ortalama Testleri İle Bir Analiz. Uluslararası Alanya İşletme Fakültesi Dergisi, 8(1) , 43-57.

DiBartolomeo, D., \& Kurtz, L. (1999). Managing Risk Exposures of Socially Screened Portfolios. Retrieved from https://www.northinfo.com/documents/63.pdf

Docekalová, M. P., \& Kocmanová, A. (2016). Composite indicator for measuring corporate sustainability. Ecological Indicators, Vol. 61, 612-623.

FTSE. (2019). FTSE4Good Index Series. Retrieved from https://www.ftse.com/products/indices/ftse4good

Garz, H., Volk, C., \& Gilles, M. (2002). More Gain than Pain - SRI: Sustainability Pays Off. WestLB Panmure.

Gök, İ. Y., \& Özdemir, O. (2017). Borsa İstanbul Sürdürülebilirlik Endeksinin Performans Karakteristiği. Sosyoekonomi, 25(34), 87-105.

Lassala, C., Apetrei, A., \& Sapena, J. (2017). Sustainability Matter and Financial Performance of Companies. Sustainability 9(9):1498, 1-16.

Lopez, M. V., Garcia, A., \& Rodriguez, L. (2007). Sustainable Development and Corporate Performance: A Study Based on the Dow Jones Sustainability Index. Journal of Business Ethics, 75 , 285-300.

Machado, M. R., Machado, M. A., \& Corrar, L. J. (2009). Desempenho do índice de sustentabilidade empresarial (ISE) da Bolsa de Valores de São Paulo. Revista Universo Contábil, 5(2) , 24-38.

Orsato, R. J., Garcia, A., Mendes-Da-Silva, W., Simonetti, R., \& Monzoni, M. (2015). Sustainability indexes: why join in? A study of the ' Corporate Sustainability Index (ISE)' in Brazil. Journal of Cleaner Production, $96,161-170$.

Ortas, E., Moneva, J. M., \& Salvador, M. (2010). Conditional volatility in sustainable and traditional stock exchange indexes:analysis of the Spanish market. Journal of Globalization, Competitiveness \& Governability, $4(2), 104-129$.

Parkinson, M. (1980). The Extreme Value Method for Estimating the Variance of the Rate of Return. The Journal of Business, 53(1), 61-65.

Rezende, I. A., Nunes, J. G., \& Portela, S. S. (2007). Um estudo sobre o desempenho financeiro do índice Bovespa de sustentabilidade empresarial. Revista de Educação e Pesquisa em Contabilidade, 2(4) , 93-122.

RobecoSAM. (2018). DJSI index family. Retrieved from https://www.sustainability-indices.com/index-familyoverview/djsi-index-family.html

Sauer, D. A. (1997). The impact of social-responsibility screens on investment performance: Evidence from the Domini 400 social index and Domini Equity Mutual Fund. Review of Financial Economics, 6(2) , 137-149.

Schröder, M. (2007). Is there a Difference? The Performance Characteristics of SRI Equity Indices. Journal of Business Finance \& Accounting, 34(1) , 331-348.

Siew, R. Y. (2015). A review of corporate sustainability reporting tools (SRTs). Journal of Environmental Management, 164 , 180-195.

Statman, M. (2000). Socially Responsible Mutual Funds. Financial Analysts Journal 56(3) , 30-39. 
C. E. Levent 11/4 (2019) 3190-3203

Sudha, S. (2015). Risk-return and Volatility analysis of Sustainability Index in India. Environ Dev Sustain, 17 , 1329-1342.

TCMB. (2019). TCMB Faiz Oranlarn (\%) Gecelik (O/N). Retrieved from http://www.tcmb.gov.tr/wps/wcm/connect/TR/TCMB+TR/Main+Menu/Temel+Faaliyetler/Para+Politik asi/Merkez+Bankasi+Faiz+Oranlari/faiz-oranlari

Vasal, V. K. (2009). Corporate Social Responsibility \& Shareholder Returns - Evidence from the Indian Capital Market. Indian Journal of Industrial Relations, 44(3) , 376-385.

WCED. (1987). Our Common Future: Report of the World Commission on Environment and Development. Oxford: Oxford University Press. 